\title{
Effects of Somatostatin Added to Insulin in a Glucose-Controlled Insulin Infusion System
}

\author{
J. L. Selam, D. Chenon, T. C. Pham, J. P. Gagnol ${ }^{2}$, C. Sany ${ }^{1}$, N. Thomas ${ }^{1}$, G. Gravagne ${ }^{1}$, \\ A. Orsetti and J. Mirouze \\ Clinique des Maladies Métaboliques et Endocriniennes and Service de Biochimie $\mathrm{C}^{1}$, Hôpital Saint-Eloi, \\ and Centre de Recherches Clin-Midy ${ }^{2}$, Montpellier, France
}

\begin{abstract}
Summary. Five insulin treated diabetics were studied on three consecutive days. Overnight variable intravenous insulin infusions were used before each study to maintain normoglycaemia and to calculate the optimal basal insulin infusion rate $(1.1 \pm$ $0.1 \mathrm{U} / \mathrm{h}$ ) which was then kept constant throughout the study day. A standard $400 \mathrm{kCal}$ breakfast with $25 \mathrm{~g}$ xylose was given at $0800 \mathrm{~h}$. When the blood glucose rose above $4.1 \mathrm{mmol} / \mathrm{l}$, an external artificial pancreas was used to infuse either extra insulin (day INS) or somatostatin for either $\mathbf{3 h}$ (day som) or the entire $8 \mathrm{~h}$ experimental period (day SOM). Peak post-prandial blood glucose values were similar on all three days. The blood glucose rebounded after the cessation of the somatostatin infusion on day som. Post-prandial blood xylose peaks were lowered by somatostatin on both days but rebounded after the cessation of the somatostatin infusion on day som. The area under the plasma and urinary xylose curves was lowered by somatostatin only on day SOM. Growth hormone and glucagon levels were not statistically different on all 3 days. Thus somatostatin, when added to an optimal insulin infusion, minimised the insulin requirements by slowing intestinal absorption, but led to rebound hyperglycaemia if not feedback controlled.
\end{abstract}

Key words: Somatostatin, insulin infusion, artificial pancreas, xylose, carbohydrate absorption, glucagon, growth hormone

Continuous insulin delivery systems using feedback (artificial pancreas) or preprogrammed (open-loop) control devices are currently the most effective methods of restoring a normal glycaemic profile in diabetic subjects [1]. Excessive insulin administration is an unavoidable problem with all such peripheral infusion $[2,3]$, particularly post-prandially [4]. Somatostatin infusion has been reported to lower the subcutaneous insulin requirements in insulin dependent diabetics $[5,6]$. Thus, the present study was carried out to establish whether somatostatin when added post-prandially to a basal IV insulin infusion might obviate the need for high post-prandial doses of insulin. The opportunity was also taken to study the effects of this bi-hormonal infusion on circulating growth hormone and glucagon and the absorption of xylose.

\section{Subjects and Methods}

\section{Subjects}

Informed consent was obtained from five insulin treated stable uncomplicated diabetics, whose clinical characteristics are shown in Table 1. No residual insulin secretion was detected in any of the patients by using urinary $\mathrm{C}$-peptide determinations. No patient was taking any drug other than insulin, or suffered from any disease other than diabetes at the time of the study.

Table 1. Clinical characteristics of subjects studied

\begin{tabular}{lllll}
\hline Patients & $\begin{array}{l}\text { Age } \\
\text { (years) }\end{array}$ & $\begin{array}{l}\text { Ideal body } \\
\text { weight } \\
(\%)\end{array}$ & $\begin{array}{l}\text { Duration of } \\
\text { diabetes } \\
\text { (years) }\end{array}$ & $\begin{array}{l}\text { SC insulin } \\
\text { doses } \\
(\mathrm{U} / \text { day) }\end{array}$ \\
\hline 1 & 35 & 88 & 29 & 48 \\
2 & 59 & 105 & 15 & 34 \\
3 & 65 & 113 & 5 & 38 \\
4 & 31 & 105 & 14 & 49 \\
5 & 61 & 110 & 19 & 54 \\
\hline Mean & 50 & 104 & 16 & 45 \\
SEM & 7 & 4 & 4 & 4 \\
\hline
\end{tabular}


Table 2. Insulin and somatostatin doses during the three periods of the study. The basal insulin infusion rate was the same on each day

\begin{tabular}{|c|c|c|c|c|c|c|}
\hline & \multirow[b]{2}{*}{$\begin{array}{l}\text { Basal insulin } \\
\text { rate } \\
(\mathrm{U} / \mathrm{h})\end{array}$} & \multirow{2}{*}{$\begin{array}{l}\text { Day INS } \\
\text { Superimposed } \\
\text { insulin } \\
\text { (U) }\end{array}$} & \multicolumn{2}{|l|}{ Day som } & \multicolumn{2}{|l|}{ Day SOM } \\
\hline & & & $\begin{array}{l}\text { Somatostatin } \\
\text { dose } \\
(\mu \mathrm{g})\end{array}$ & $\begin{array}{l}\text { Somatostatin } \\
\text { rate } \\
(\mu \mathrm{g} / \mathrm{h})\end{array}$ & $\begin{array}{l}\text { Somatostatin } \\
\text { dose } \\
(\mu \mathrm{g})\end{array}$ & $\begin{array}{l}\text { Somatostatin } \\
\text { rate } \\
(\mu \mathrm{g} / \mathrm{h})\end{array}$ \\
\hline 1 & 0.8 & 15 & 600 & 327 & 900 & 300 \\
\hline 2 & 1.2 & 27 & 800 & 300 & 2000 & 444 \\
\hline 3 & 1.0 & 15 & 500 & 300 & 600 & 240 \\
\hline 4 & 1.3 & 9 & 250 & 500 & 600 & 185 \\
\hline 5 & 0.7 & 24 & 600 & 360 & 1600 & 267 \\
\hline Mean & 1.0 & 18 & 550 & 357 & 1140 & 287 \\
\hline SEM & 0.1 & 3 & 89 & 37 & 282 & 44 \\
\hline
\end{tabular}

Day INS = basal insulin plus glucose-controlled insulin infusion available for $8 \mathrm{~h}$

Day som = basal insulin plus glucose-controlled somatostatin infusion available for $3 \mathrm{~h}$

Day $S O M=$ basal insulin plus glucose-controlled somatostatin infusion available for $8 \mathrm{~h}$
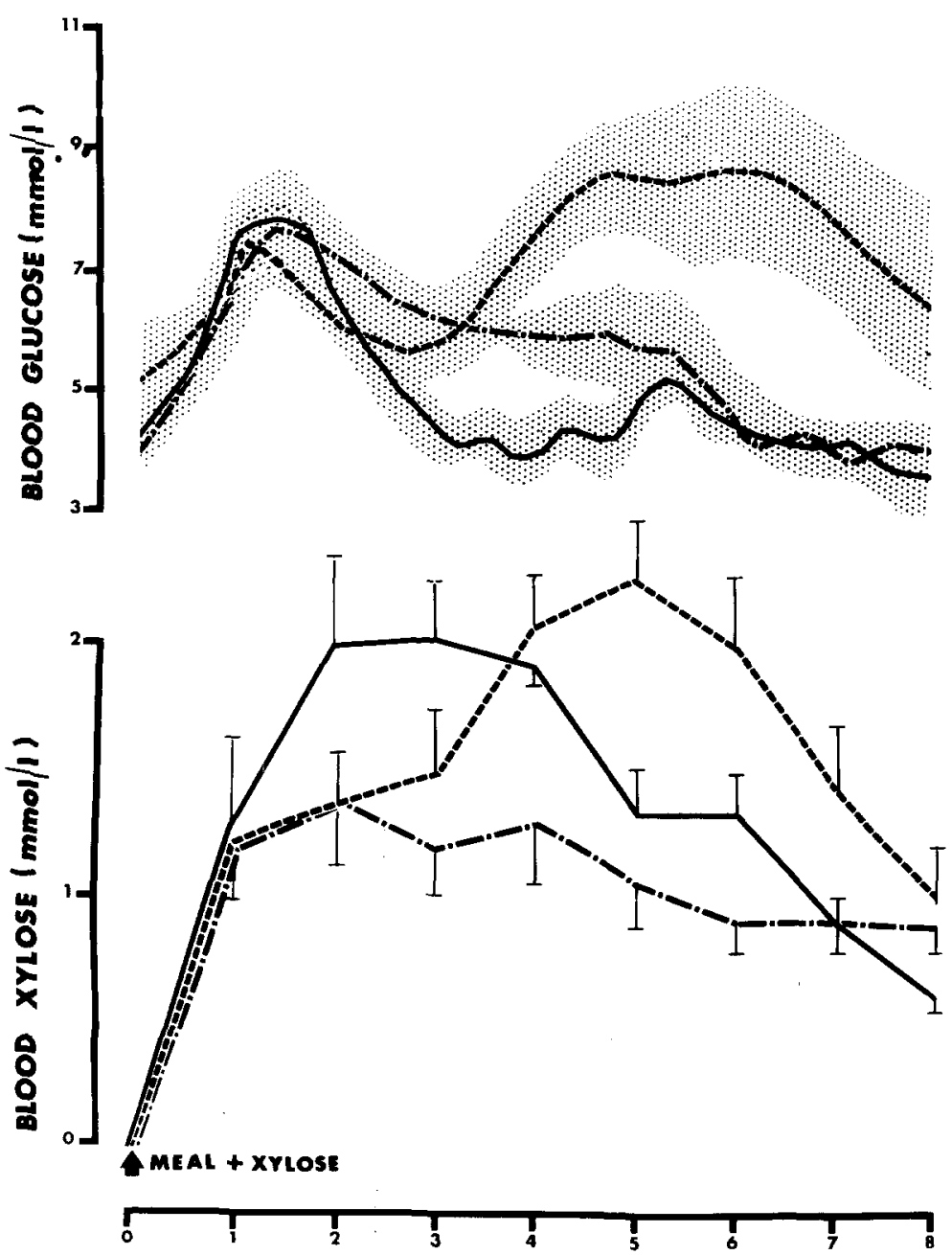

TIME (hours)
Fig. 1. Mean \pm SEM blood glucose and plasma xylose on day INS (-), day som (----) or day SOM $(-\cdot-)$. Blood glucose: INS results were significantly different $(p<0.05)$ from SOM results between 2 and $3 \mathrm{~h}$, and from som results between 3 and $8 \mathrm{~h}$. SOM and som results differed significantly $(p<0.05)$ between 4 and $7 \mathrm{~h}$. Plasma xylose: INS results differed significantly $(p<0.05)$ from SOM results at 3 and $4 \mathrm{~h}$, and from som results at $5 \mathrm{~h}$. SOM and som results differed significantly at $5 \mathrm{~h}$ 


\section{Experimental Protocol}

Subjects were studied at bed-rest on three consecutive randomlyordered days from $0800 \mathrm{~h}$ to $1600 \mathrm{~h}$.

On the night preceding each period of study, insulin was infused IV by a variable rate pump in order to begin each experiment at normoglycaemic levels. In addition, the mean individual basal infusion rate was calculated from the first night of infusion and then held constant throughout the three $8 \mathrm{~h}$ studies.

A standard breakfast, containing $400 \mathrm{kCal} \mathrm{(40 \%} \mathrm{carbohy-}$ drate, $20 \%$ protein and $40 \%$ fat) was given at $0800 \mathrm{~h}$ together with $25 \mathrm{~g}$ xylose (Prolabo, France) dissolved in $200 \mathrm{ml}$ water. No additional meal or drink was given before $1600 \mathrm{~h}$. When blood

Table 3. Area under plasma xylose curves, and urinary xylose elimination

\begin{tabular}{lccc}
\hline & Day INS & Day som & Day SOM \\
\hline $\begin{array}{l}\text { Plasma xylose } \\
\text { areas under the } \\
\text { curves } \\
\text { (arbitrary units) }\end{array}$ & $167 \pm 12$ & $186 \pm 12$ & $126 \pm 16$ \\
\hline Urinary xylose & & & \\
elimination (mmol) & & $14 \pm 3$ & $13 \pm 2$ \\
$\quad 0-4 \mathrm{~h}$ & $16 \pm 2$ & $19 \pm 2$ & $13 \pm 2$ \\
$4-8 \mathrm{~h}$ & $16 \pm 2$ & $33 \pm 3$ & $26 \pm 5$ \\
$\quad$ Total & $32 \pm 2$ & & \\
\hline
\end{tabular}

See Table 2 for abbreviations. $*: p<0.05 * *: p<0.01$ glucose rose above $4.1 \mathrm{mmol} / \mathrm{l}$, an infusion given by an external artificial pancreas [7] was superimposed on the basal constant insulin rate until the blood glucose returned to $6.0 \mathrm{mmol} / \mathrm{l}$ or less. On day INS the reservoir of the artificial pancreas was filled with insulin (Actrapid), Novo) diluted in $0.154 \mathrm{mmol} / \mathrm{l}$ ) saline to a final concentration of $3 \mathrm{U} / \mathrm{ml}$. According to the algorithm used [8] the maximum infusion rate was $15 \mathrm{U} / \mathrm{h}$. On day som insulin was replaced in the reservoir by cyclic somatostatin (Clin-Midy, France) diluted in $0.154 \mathrm{mmol} / 1$ saline to a final concentration of $100 \mu \mathrm{g} / \mathrm{h}$. After $3 \mathrm{~h}$, the feedback somatostatin infusion was stopped whatever the blood glucose level in order to mimic the conditions of a pre-programmed infusion system. On day SOM, somatostatin was infused as on day som but the somatostatin primed artificial pancreas was left in the closed-loop mode for the whole 8-h period.

\section{Analytical Methods}

Blood was taken from the ante-cubital vein of the non-infused arm. Heparinized blood was drawn continuously $(1.3 \mathrm{ml} / \mathrm{h})$ for continuous blood glucose determination using a Technicon autoanalyzer incorporated into our artificial pancreas [7]. In addition, $10 \mathrm{ml}$ blood were taken hourly and immediately centrifuged. Urine was collected every $4 \mathrm{~h}$. D-Xylose was measured in plasma and urine by a colorimetric method [9]. Absence of interference with glucose was first verified. Immunoreactive plasma glucagon was measured using the Unger antibody $30 \mathrm{~K}$ [10]. Plasma growth hormone was measured by a double antibody technique [11].

\section{Statistical Methods}

The results were expressed as mean \pm SEM. Differences between the mean results of the three periods were analyzed for statistical significance by Student's paired $t$ test.
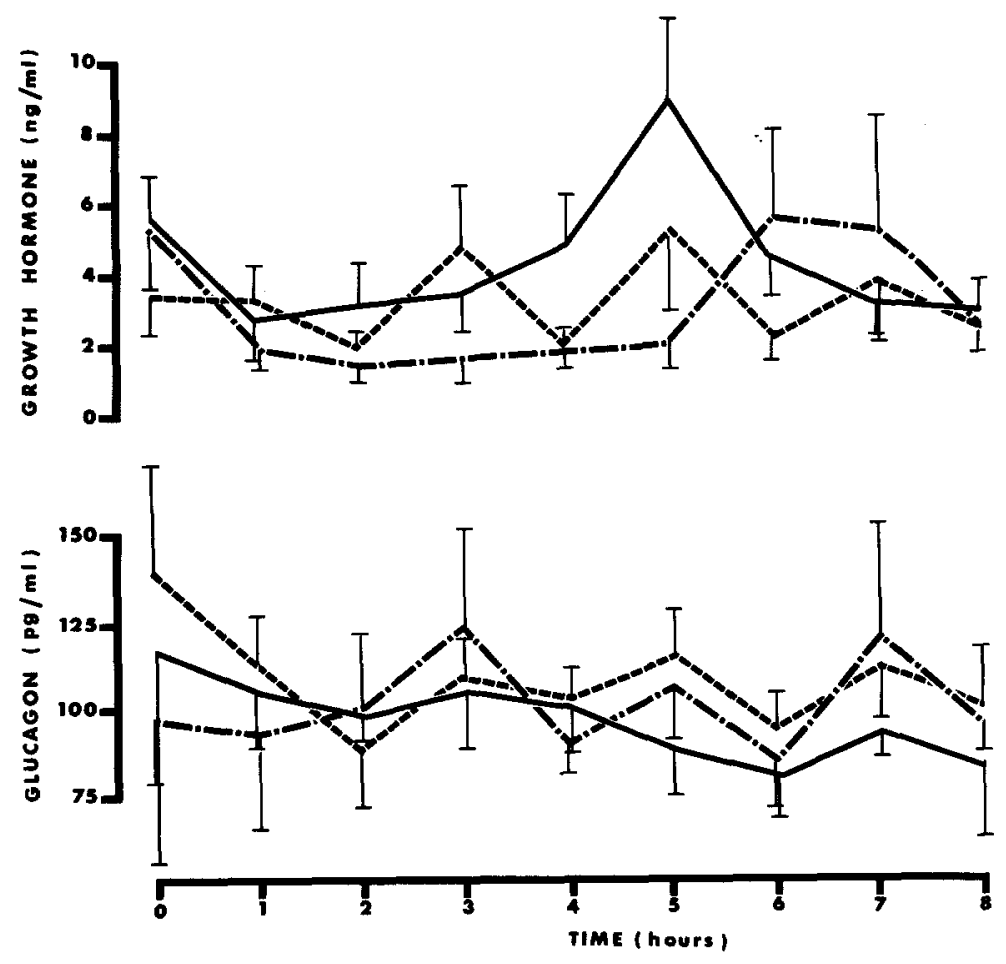

Fig. 2. Mean \pm SEM plasma glucagon and growth hormone on day INS (-) day som (--_-) or day $\operatorname{SOM}(-\cdot-)$ 


\section{Results}

\section{Insulin and Somatostatin Doses (Table 2)}

The mean basal insulin infusion rate was $1.0 \pm$ $0.1 \mathrm{U} / \mathrm{h}$. An additional $18 \pm 3 \mathrm{U}$ were infused postprandially on day INS by the artificial pancreas. Hence a total of $26 \mathrm{U}$ was infused on day INS compared with $8 \mathrm{U}$ on days som or SOM.

The doses of somatostatin infused on days som and SOM were $550 \pm 89$ and $1140 \pm 282 \mu \mathrm{g}$ respectively at a rate of $357 \pm 37$ and $287 \pm 44 \mu \mathrm{g} / \mathrm{h}$.

\section{Blood Glucose Control (Fig. 1)}

Post-prandial glycaemic excursions were similar with the three methods. Maximum blood glucose values were $7.7 \pm 0.6 \mathrm{mmol} / 1$ at $69 \pm 7 \mathrm{~min}$ on day INS, $7.3 \pm 0.3 \mathrm{mmol} / 1$ at $58 \pm 14 \mathrm{~min}$ on day som and $7.7 \pm 0.6 \mathrm{mmol} / \mathrm{l}$ at $84 \pm 6 \mathrm{~min}$ on day SOM. Blood glucose returned rapidly to the initial values on day INS but exhibited a large rebound on day som beginning immediately after the cessation of somatostatin infusion. Values on day SOM were intermediate, showing no rebound but a slower return to initial values which were not reached before $6 \mathrm{~h}$.

\section{Xylose}

Plasma xylose results are shown on the lower part of Fig. 1. The postprandial xylose peaks were lower during somatostatin infusion, being $1.5 \pm 0.3 \mathrm{mmol} / 1$ on day som and $1.3 \pm 0.2 \mathrm{mmol} / \mathrm{l}$ on day SOM versus $2.1 \pm 0.3 \mathrm{mmol} / 1$ on day INS $(p<0.05$ between INS and SOM). A rebound was noted on day som only. After stopping the somatostatin infusion plasma $x y-$ lose values reached $2.5 \pm 0.2 \mathrm{mmol} / \mathrm{l}$ at $264 \pm$ 14 min versus $1.6 \pm 0.2(p<0.05)$ and $1.1 . \pm 0.2$ $(p<0.01)$ on days som, INS and SOM respectively. The areas under the plasma xylose and total xylosurias curves were similar on days INS and som, but $25 \%$ lower on day SOM $(p<0.01)$ (Table 3$)$.

\section{Growth Hormone and Glucagon (Fig. 2)}

Fasting plasma growth hormone values were in the normal range $(3-6 \mathrm{ng} / \mathrm{ml})$. Post-prandial values decreased similarly on the 3 days and showed a late rebound on day INS only. Plasma glucagon was initially in the upper normal range $(40-100 \mathrm{pg} / \mathrm{ml})$ and did not exhibit any clear inhibition or rebound during the three studies.

\section{Discussion}

This study shows that in the presence of a basal infusion of insulin, the post-prandial rise in blood glucose seen in insulin-dependent diabetics may be as effectively controlled by a timed infusion of somatostatin as by insulin. Somatostatin infused at $300 \mu \mathrm{g} / \mathrm{h}$ was equivalent to an insulin dose of 18 units. Thus, a bi-hormonal system where mealtime infusions of somatostatin are superimposed on a continuous basal insulin infusion may reduce the hyperinsulinism which invariably occurs when doses of insulin are given prandially [2], and consequently decrease the potential risks of high insulin levels [12]. On the other hand, the absence of any post-prandial increase of insulin values may result in abnormalities of amino-acid and lipid metabolism. In our experimental model, the antidiabetic effect of somatostatin seems to result from a decrease in carbohydrate absorption [13-15], rather than a direct hormonal effect on blood glucose. The paradoxical findings of an unchanged growth hormone and glucagon $[16-17]$ may simply be due to their prior normalisation by the overnight insulin infusion [18-20] although transitory hormonal change cannot be excluded between the samples.

Christensen et al., studying patients in the fasting state, found similar glycaemic rebound to ourselves on stopping somatostatin infusion but also noted a parallel rebound of growth hormone and glucagon [17]. This apparently conflicting result may have been due to the lower infusion of insulin.

In conclusion therefore somatostatin could serve to replace post-prandial doses of insulin in an insulin dependent blood glucose regulating system and thus reduce the quantities of insulin infused. Somatostatin acts primarily by reducing or delaying carbohydrate absorption. Whilst this is less than the reduction seen in states of malabsorption, the potential long term consequences will require consideration and could limit the potential use of somatostatin.

Acknowledgements. The authors wish to thank Clin-Midy Laboratory, Montpellier (Drs. R. Roncucci, J. P. Gagnol, C. Jacob) who generously provided somatostatin, and Dr. T. J. Wilkin for his aid in the preparation of the manuscript.

\section{References}

1. Santiago JV, Clemens AH, Clarke WL, Kipnis DM (1979) Closed-loop and open-loop devices for blood glucose control in normal and diabetic subjects. Diabetes 28: 71-84

2. Botz CK, Marliss EB, Leibel BS, Zingg W, Zinman B, Albisser AM (1979) Blood glucose regulation using closed- and openloop insulin delivery systems. II. Peripheral primed square wave infusions. Diabetologia 17: 45-49 
3. Pickup JC, Keen H, Viberti GC, White MC, Kohner EM, Parsons JA, Alberti KGMM (1980) Continuous subcutaneous insulin infusion in the treatment of diabetes. Diabetes Care 3: 290-300

4. Goriya Y, Bahoric A, Marliss EB, Zinman B, Albisser AM (1979) Glycemic regulation using a programmed insulin delivery device. III. Long term studies on diabetic dogs. Diabetes 28: 558-564

5. Gerich JE, Schultz TA, Lewis SB, Karam JH (1977) Clinical evaluation of somatostatin as a potential adjunct to insulin in the management of diabetes mellitus. Diabetologia 13: $537-544$

6. Meissner C, Thum CH, Beischer W, Schroder KE, Pfeiffer EF (1975) Antidiabetic action of somatostatin-assessed by the artificial pancreas. Diabetes 24: 988-996

7. Ferrand D, Renaud JF, Louis G, Pistoulet B (1979) Numeric control of the transfer factor of insulin/glucose by a programmable device. Proceedings of a workshop meeting on feedback controlled and preprogrammed insulin infusion in diabetes mellitus. May 1978, Schloss Reisenburg (West-Germany), Thieme, Stuttgart, pp 141-145

8. Mirouze J, Selam JL, Pham TC, Cavadore D (1977) Evaluation of exogenous insulin homeostasis by the artificial pancreas in insulin-dependent diabetes. Diabetologia 13: 273-278

9. Roe JH, Rice EW (1948) A photometric method for the determination of free pentoses in animal tissues. J Biol Chem 173: $507-512$

10. Aguilar-Parada AM, Eisentraut I, Unger RH (1969) Pancreatic glucagon secretion in normal and diabetic subjects. Am J Med Sci 275: 415-419

11. Molinatti GM, Massara F, Strumia E, Pennisi F, Scassellati GA, Vancheri L (1969) Radioimmunoassay of human growth hormone. J Nucl Biol Med 13: 26-36

12. Stout RW (1979) Diabetes and atherosclerosis: the role of insulin. Diabetologia 16: 141-150

13. Wagner H, Hengst K, Jansens H, Gerlach U (1978) Effects of somatostatin on mono- and disaccharides in small intestine in vivo and in vitro in man and rats. Metabolism 27: 1329-1332

14. Wahren J, Felig P (1976) Influence of somatostatin on carbohydrate disposal and absorption in diabetes mellitus. Lancet I: $1213-1216$

15. Schusdziarra V, Harris V, Arimura A, Unger RH (1979) Evidence for a role of splanchnic somatostatin in the homeostasis of ingested nutrients. Endocrinology 104: 1705-1708

16. Raskin P, Unger RH (1978) Hyperglucagonemia and its suppression. Importance in the metabolic control of diabetes. N Engl J Med 299: 433-436

17. Christensen SE, Hansen AP, Weeke J, Lundbaek K (1978) 24-hour studies of the effects of somatostatin on the levels of plasma growth hormone, glucagon and glucose in normal subjects and juvenile diabetics. Diabetes 27: 300-306

18. Gerich JE, Tsalikian E, Lorenzi M, Schneider V, Bohannon NV, Gustafson G, Karam JH (1975) Normalization of fasting hyperglucagonemia and excessive glucagon response to intravenous arginine in human diabetes mellitus by prolonged infusion of insulin. J Clin Endocrinol Metab 41: 1178-1180

19. Merimee TJ, Fitzgerald CR, Gold LA, McCourt JP (1979) Characteristics of growth hormone secretion in clinically stable diabetes. Diabetes 28: 308-312

20. Tamborlane WV, Sherwin RS, Koivisto V, Hendler R, Genel M, Felig P (1979) Normalization of the growth hormone and catecholamine response to exercise in juvenile-onset diabetic subjects treated with a portable insulin infusion pump. Diabetes $28: 785-788$

Received: 30 May 1980

and in revised form: 14 April 1981

Dr. J. L. Selam

Clinique des Maladies Métaboliques et Endocriniennes

Hôpital St. Eloi

F-34059 Montpellier Cedex, France 